\title{
KETERAMPILAN SOSIAL PUSTAKAWAN DALAM MEMBERIKAN PELAYANAN BERMUTU DI PERPUSTAKAAN
}

\author{
Machsun Rifauddin*
}

Pengutipan: Rifauddin, M. (2017). Keterampilan sosial pustakawan dalam memberikan pelayanan bermutu di perpustakaan. Khizanah al-Hikmah : Jurnal Ilmu Perpustakaan, Informasi, dan Kearsipan, 5(1), 102-112.

DOI: http:/ /dx.doi.org/10.24252/kah.v5i1a9

*Mahasiswa Pascasarjana Jurusan Ilmu Perpustakaan UIN Sunan Kalijaga Yogyakarta machsunr@yahoo.com

\begin{abstract}
ABSTRAK
Perpustakaan sebagai lembaga pelayanan jasa informasi harus terus berkembang seiring dengan kebutuhan pemustaka yang semakin kompleks dan beragam. Perpustakaan sudah seharusnya dikelola oleh pustakawan yang memiliki keterampilan sosial khusus dalam memberikan pelayanan yang bermutu kepada pemustaka. Pelayanan yang bermutu menjadi tolak ukur kepuasan pemustaka. Artikel ini disusun berdasarkan kajian literatur yang diambil dari berbagai sumber rujukan. Tujuan penulisan artikel ini adalah untuk memberikan gambaran secara umum bagaimana menjadi pustakawan profesional yang terampil dalam memberikan pelayanan bermutu kepada pemustaka secara konseptual. Pelayanan bermutu dapat dilakukan dengan menyampaikan sifat positif, mengenali kebutuhan pelanggan, memenuhi kebutuhan pelanggan, dan memastikan pemustaka kembali lagi atau merasa puas. Pustakawan juga dituntut untuk memiliki kemampuan interpersonal yang ditunjukkan dengan berkomunikasi secara efektif kepada pemustaka.
\end{abstract}

Kata kunci: Keterampilan sosial, pustakawan, pelayanan bermutu, perpustakaan

\section{ABSTRACT}

Library information services as an institution should continue to evolve along with user needs of an increasingly complexs. The library was supposed to run by librarians who have specific social skills in providing quality service to the end users. Service quality became measure user satisfaction. This article is based on the study of literature drawn from various reference sources. The purpose of this article is to give an overview in general how to be professional librarians in providing quality service to user as conceptually. Quality service can be done with positive atitude, recognize customer needs, satisfy customer needs, and make sure the end users back again or feel satisfied. Librarians also are required to have interpersonal skills demonstrated by communicating effectively to the end users.

Key words: Sosial skills, librarian, quality service, library

\section{PENDAHULUAN}

Perpustakaan sebagai lembaga yang bergerak di bidang layanan jasa informasi memiliki peran yang sangat penting. Segala macam bentuk Informasi harus disediakan perpustakaan untuk membantu para pemustaka dalam menghadapi persoalan yang dihadapinya. Perpustakaan juga berperan sebagai pelayanan publik dijelaskan dalam Undang-Undang No. 43 tahun 2007 tentang Perpustakaan, pasal 14 ayat (1) 
yang menyatakan bahwa layanan perpustakaan dilakukan secara prima dan berorientasi kepada kepentingan pemustaka (MPR RI, 2007). Perpustakaan yang berkualitas adalah perpustakaan yang mampu menjawab setiap persoalan informasi yang dibutuhkan oleh setiap pemustakanya. Untuk memenuhi kebutuhan dan kepuasan pemustaka tersebut perpustakaan saat ini dituntut untuk mampu mengikuti perubahan sosial, perubahan dalam kebutuhan informasi, perubahan dalam berinteraksi dengan orang lain, dan dalam berkompetisi. Oleh karena itu kelengkapan koleksi ditunjang dengan pustakawan yang terampil akan menjadi faktor yang dominan dalam membantu pemustaka dalam melakukan penelusuran informasi dengan lebih cepat dan tepat.

Menurut Kepmenpan (1993) No. 81 tentang penyelenggaraan pelayanan publik, unsur-unsur pelayanan meliputi: kesederhanaan, kejelasan dan kepastian, keterbukaan, keamanan, efisiensi, ekonomis, keadilan merata, dan ketepatan waktu. Sesuai dengan kandungan definisi tersebut berarti para birokrat termasuk para pegawai atau karyawan instansi pemerintah hendaknya harus memberikan layanan yang terbaik kepada pengguna jasa (masyarakat) dan bukan hanya kepada orang yang dilayaninya. Oleh sebab itu keterampilan sosial pustakawan sangat sangat diperlukan dalam meningkatkan pelayanan di dalam perpustakaan. Seorang pustakawan dalam aktifitasnya diharapkan untuk selalu mengedepankan kebutuhan penggunanya, mempunyai kemampuan berkomunikasi yang baik, mempunyai kemampuan teknis perpustakaan yang tinggi, dan mempunyai kemampuan dalam memanfaatkan kemajuan teknologi informasi.
Untuk dapat menunjukkan perannya baik dalam lingkungan perpustakaan dan masyarakat, seorang pustakawan harus memiliki keunggulan dalam profesi. Pustakawan harus memiliki kompetensi personal yang meliputi, sikap, keterampilan, dan kemampuan perorangan untuk bekerja efektif dan memberikan sumbangan positif bagi organisasi, dan bagi masyarakat pada umumnya. Tujuan utama penulisan artikel ini adalah untuk menjelaskan bagaimana menjadi seorang pustakawan yang terampil dalam memberikan pelayanan bermutu kepada pemustaka secara konseptual berdasarkan kajian literatur.

\section{PEMBAHASAN}

\section{a. Keterampilan Sosial}

Keterampilan dalam Kamus Besar Bahasa Indonesia adalah kecakapan untuk menyelesaikan tugas, sedangkan sosial adalah berkenaan dengan masyarakat (2008, 1180). Merrel $(2008,1)$ memberikan pengertian keterampilan sosial sebagai perilaku spesifik, inisiatif, mengarahkan pada hasil sosial yang diharapkan sebagai bentuk perilaku seseorang. Libet dan Lewinsohn dalam Cartledge (1995, 73) mendefinisikan keterampilan sosial sebagai-kemampuan yang kompleks untuk menunjukkan perilaku yang baik dinilai secara positif atau negatif oleh lingkungan, dan jika perilaku itu tidak baik akan diberikan hukuman atau sanksi oleh lingkungan. Keterampilan sosial menurut Comb dan Slaby (1997, 162) sebagai berikut:

"The social skill is the ability to interact with others in a given social context in specific ways that are socially acceptable or valued at the same time persobality benefecial, manually benefecial, or benefecial primary to others". 
Keterampilan sosial adalah kemampuan berinteraksi dengan orang lain dalam suatu konteks sosial dengan cara yang spesifik sehingga dapat diterima atau dinilai menguntungkan bagi dirinya, mutu kehidupannya, dan orang lain.

Bellack and Hersen (1977, 145) juga memberikan definisi keterampilan sosial sebagai berikut :

"Social skills as individual's ability to express both positive and negative feelings in the interpersonal context without suffering consequent loss of social reinforcement in a large variety of interpersonal contexts (inolving) the coordinated delivery of appropriate verbal and non verbal response".

Keterampilan sosial mempunyai makna sebagai kemampuan individu dalam mengungkapkan perasaan baik perasaan positif maupun perasaan negatif dalam hubungannya dengan orang lain tanpa kehilangan penguatan sosial dan dalam berbagai ragam hubungan dengan orang lain yang mencakup respon verbal dan non verbal.

Berdasarkan pendapat beberapa tokoh di atas dapat disimpulkan bahwa yang dimaksud dengan keterampilan sosial adalah kemampuan individu dalam berinteraksi baik secara verbal maupun non verbal agar dapat beradaptasi dan diterima oleh lingkungan sekitar.

\section{b. Pelayanan}

Istilah pelayanan berasal dari kata "layan" yang artinya menolong menyediakan segala apa yang diperlukan oleh orang lain untuk perbuatan melayani. Pada dasarnya setiap manusia membutuhkan pelayanan, bahkan secara ekstrim dapat dikatakan bahwa pelayanan tidak dapat dipisahkan dengan kehidupan manusia (Sinambela, 2005, 3). Pelayanan adalah proses pemenuhan kebutuhan melalui orang lain secara langsung (Moenir, 2006, 16-17). Ratminto dan Atik $(2005,2)$ mendefinisikan pelayanan sebagai suatu aktivitas atau serangkaian aktivitas yang bersifat tidak kasat mata (tidak dapat diraba) yang terjadi akibat adanya interaksi antara konsumen dengan karyawan atau hal-hal lain yang disediakan oleh perusahaan pemberi pelayanan yang dimaksudkan untuk memecahkan permasalahan konsumen/ pelanggan.

Pelayanan menurut Lovelock $(2002,5)$ didefinisikan sebagai kegiatan ekonomi yang menciptakan dan memberikan manfaat bagi pelanggan pada waktu dan tempat tertentu, sebagai hasil dan tindakan mewujudkan perubahan yang diinginkan dalam diri atau atas nama penerima jasa tersebut. Sedangkan pengertian pelayanan menurut Kotler (2003, 85) yaitu setiap tindakan atau kegiatan yang dapat ditawarkan oleh satu pihak kepada pihak lain pada dasarnya tidak berwujud dan tidak mengakibatkan kepemilikan apapun. Kasmir (2005, 15) mengemukakan bahwa pelayanan diberikan sebagai tindakan atau perbuatan seseorang untuk memberikan kepuasan kepada pelanggan atau nasabah.

Jadi pelayanan dapat didefinisikan sebagai tindakan atau kinerja yang menciptakan manfaat bagi pelanggan dengan mewujudkan perubahan yang diinginkan, sehingga pelayanan tersebut memiliki nilai tersendiri bagi pelanggan hubungannya dalam menciptakan nilainilai positif bagi pelanggan. Sedangkan pelayanan perpustakaan sendiri adalah penyediaan segala bentuk bahan pustaka secara tepat dan akurat sesuai kebutuhan pengguna jasa perpustakaan dan 
penyedia berbagai sarana penelusuran informasi. Sasaran utama pelayanan adalah fokus kepada pelanggan, dan kepuasan pelanggan adalah orientasi utamanya. (Rahayu dan Kiemas, 2011, 1314).

\section{c. Kualitas Pelayanan}

Menurut Sutarno (2005, 112) jika layanan kepada pelanggan memuaskan maka baiklah kinerjanya, sebaliknya apabila layanan yang diberikan belum memuaskan maka dapat dianggap bahwa perpustakaan tersebut belum mampu melayani dengan baik. Sedangkan menurut Tjiptono (2005, 121) "kualiltas pelayanan merupakan suatu alat ukur seberapa bagus tingkat pelayanan yang diberikan sehingga mampu/sesuai dengan harapan pelanggan".

Kepuasan pelanggan menjadi tolak ukur baik tidaknya sebuah pelayanan. Dalam perpustakaan banyak tugas yang harus dilakukan oleh pustakawan dalam melayani pemustakanya, terkadang banyak hal-hal yang menjadi kebutuhan dan keinginan pemustaka bahkan terkadang terlalu berlebihan. Pustakawan dalam hal ini harus pandai-pandai dalam memberikan pelayanan seperti yang diinginkan pemustakanya. Berikut ciri-ciri pelayanan yang baik menurut Kasmir $(2005,15)$ yaitu:

1) Bertanggung jawab kepada nasabah sejak awal hingga selesai,

2) Mampu melayani secara cepat dan tepat,

3) Mampu berkomunikasi,

4) Mampu memberikan jaminan kerahasiaan setiap transaksi,

5) Memiliki pengetahuan dan kemampuan yang baik,

6) Berusaha memahami kebutuhan nasabah,
7) Mampu memberikan kepercayaan kepada nasabah.

Sedangkan Sutarno (2005, 112) mengemukakan layanan yang efektif adalah yang dapat memenuhi keinginan pemakai dalam hal:

1) Penyediaan informasi yang sesuai dengan keinginan pemakai,

2) Waktu yang tepat, leluasa, memadai dan tidak terlalu mengikat, termasuk kesempatan sore dan malam untuk kelompok masyarakat,

3) Kebebasan, tata cara dan akses informasi, tidak kaku dengan pengawasan longgar, tidak terlalu ketat, tertib, kondusif dan simpatik,

4) Suasana yang menyenangkan, aman, tenang, tentram, jauh dari kegaduhan dan kebisingan,

5) Sikap dan perilaku petugas yang penuh perhatian, ramah, santun, bersifat membimbing, memandu, penuh perhatian, menguasai masalah,

6) Tata tertib yang sederhana, mudah dipahami, diikuti dan dilaksanakan,

7) Adanya fasilitas dan kemudahan yang lain seperti: panduan, petunjuk, informasi singkat atau yang lain,

8) Menimbulkan kesan yang baik, menyenangkan dan memuaskan sehingga orang ingin kembali lagi,

9) Berorientasi kepada pelangan/konsumen dan bersifat mandiri.

Untuk menilai kualitas pelayanan tersebut Parasuraman dkk, (2002, 26) mengelompokkan pelayanan (jasa) ke dalam 5 dimensi yaitu:

1) Bukti Langsung (tangible), yaitu: sebagai fasilitas yang dapat dilihat dan digunakan perusahaan dalam upaya memenuhi kepuasan pelanggan,seperti gedung kantor, 
peralatan kantor, penampilan karyawan dan lain lain,

2) Kendala (Reliability), yaitu: kemampuan memberikan pelayanan kepada pelanggan sesuai dengan yang diharapkan, seperti kemampuan dalam menepati janji, kemampuan memecahkan masalah dan kemampuan untuk meminimumkan kesalahan,

3) Daya Tanggap (Responsiveness), yaitu sebagai sikap tanggap, mau mendengarkan dan merespon pelanggan dalam upaya memuaskan pelanggan, misalnya: mampu memberikan informasi secara benar dan tepat, tidak menunjukan sikap sok sibuk dan mampu memberikan pertolongan dengan segera.

4) Jaminan (Assurance), yaitu: kemampuan karyawan dalam menimbulkan kepercayaan dan keyakinan pelanggan melalui pengetahuan, kesopanan serta menghargai perasaan pelanggan,

5) Kepedulian/Empati (Emphaty), yaitu: kemampuan atau kesediaan karyawan memberikan perhatian yang bersifat pribadi, seperti bersikap ramah, memahami kebutuhan dan peduli kepada pelanggannya.

Konsep kualitas pelayanan juga dapat pula melalui "consumer behaviour" (perilaku konsumen) yaitu perilaku yang dimainkan oleh konsumen dalam mencari, membeli, menggunakan dan mengevaluasi suatu produk pelayanan yang diharapkan mampu memenuhi kebutuhannya. Keputusan-keputusan konsumen untuk mengkonsumsi atau tidak mengkonsumsi suatu barang atau jasa dipengaruhi berbagai faktor, antara lain persepsinya terhadap kualitas pelayanan. Hal ini menunjukkan adanya interaksi yang kuat antara kepuasan konsumen dengan kualitas pelayanan
(Pasolong, 2007, 135). Pelayanan yang berkualitas atau pelayanan prima yang berorientasi pada pelanggan sangat tergantung pada kepuasan pelanggan. Salah satu ukuran keberhasilan menyajikan pelayanan yang berkualitas sangat tergantung pada tingkat kepuasan pelanggan yang dilayani (Sampara, 2000: 8). Pendapat tersebut artinya kepuasan pelanggan lebih utama atau lebih didahulukan apabila ingin mencapai kinerja pelayanan yang berkualitas.

Rahayuningsih $(2007,85)$ menyatakan pelayanan perpustakaan merupakan kegiatan memberikan layanan informasi kepada pengguna perpustakaan dengan menggunakan prinsip-prinsip dasar: (1) pelayanan bersifat universal, layanan tidak hanya diberikan kepada individuindividu tertentu, tetapi diberikan kepada pengguna secara umum, (2) pelayanan berorientasi pada pengguna, dalam arti untuk kepentingan para pengguna, bukan kepentingan pengelola, (3) menggunakan disiplin, untuk menjamin keamanan dan kenyamanan dalam memanfaatkan perpustakaan, (4) sistem yang dikembangkan mudah, cepat, dan tepat.

\section{d. Keterampilan Pustakawan dalam Memberikan Pelayanan Bermutu}

Pustakawan melakukan fungsinya dalam struktur kehidupan masyarakat sebagai penyedia informasi, pendukung kehidupan, yaitu bertanggung jawab khusus untuk menjaga keteraturan informasi dan pemenuhan kebutuhan informasi yang tekait, dalam bentuk penerapan peraturan untuk mengelola informasinya maupun dalam bentuk upaya pencegahan ketidakpuasan terhadap pemenuhan kebutuhan informasi agar masyarakat dapat hidup dan bekerja dalam kebutuhan informasi yang terpenuhi. Kegiatan-kegiatan pustakawan berkenaan dengan masalah- 
masalah kebutuhan informasi yang terkait yaitu berkenaan dengan gejala kebutuhan yang ada dalam kehidupan intelektual sosial dalam suatu masyarakat.

Peran pustakawan pada hakikatnya melakukan pelayanan manusia (human services) sehingga sarana pelayanan untuk mengakses informasi dalam koleksi perpustakaan sesuai dengan kebutuhan pemakai sangat penting dan menunjang pelaksanaan pekerjaan pustakawan dalam memenuhi kebutuhan informasi bagi pihak yang bersangkutan dan dalam kerjasama.

Keberhasilan perpustakaan sangat ditentukan layanan yang diberikan kepada pemakai. Layanan perpustakaan sebenarnya merupakan suatu proses aktivitas yang mencakup perencanaan, implementasi dan monitoring. Efektifitas layanan harus diukur dalam konteks sejauh mana layanan dapat memuaskan pemakainya bukan sekedar seberapa banyak yang dapat diraih (Bawden dan Blakeman, 1990, 49). Layanan perpustakaan akan semakin bermutu jika tingkat keterpakaian koleksi dan kepuasan pemakai semakin meningkat. Oleh karena itu, agar mutu layanan perpustakaan meningkat, maka pengelola perpustakaan harus dapat merespon kebutuhan pemustaka.

Permasalahan layanan yang sering ditermukan di perpustakaan antara lain:

1) Belum adanya standar pelayanan yang diatur dalam peraturan perundangundangan dan standar perpustakaan,

2) Sarana dan prasarana yang kurang memadai,

3) Rendahnya kualitas dan kuantitas sumber daya manusia perpustakaan pada semua jenis perpustakaan,
4) Belum optimalnya pendayagunaan teknologi informasi dan komunikasi di perpustakaan,

5) Keterbatasan anggaran.

Dari berbagai isu yang terjadi di lapangan, isu paling sentral dan kerap ditemui di perpustakaan adalah permasalahan sumber daya manusia yang dianggap masih kurang dan belum memenuhi standar operasional peprustakaan. Pustakawan memainkan peran utama dalam pelayanan terhadap masyarakat sebagai pemustaka. Seorang pustakawan harus mengetahui langkahlangkah strategis dalam rangka memuaskan pelanggan (pemustaka). Pemberian pelayanan yang bermutu merupakan kunci utama dalam pemenuhan kebutuhan pemustaka, maka dari itu seorang pustakawan harus memiliki keterampilan sosial khusus.

Pustakawan dituntut untuk memberikan layanan yang baik kepada para pemustaka. Kecakapan, ketangkasan (skill), sikap bersahabat dan menyenangkan dari pustakawan saat melakukan pelayanan kepada pemustaka harus memiliki standar khusus. Bentuk keterampilan pustakawan yang harus dimiliki dapat berupa keterampilan terhadap teknologi, keterampilan antar perorangan dan mimiliki jiwa kepemimpinan. Bentuk keterampilan antar perorangan demi menghasilkan pelayanan bermutu dijelaskan oleh Martin (2005, 19) melalui langkah-langkah sebagai berikut:

1) Menyampaikan sikap positif,

2) Mengenali kebutuhan pelanggan,

3) Memenuhi kebutuhan pelanggan,

4) Memastikan pelanggan kembali lagi.

Apabila diaplikasikan dalam perpustakaan maka beberapa 
keterampilan pokok yang harus dimiliki oleh setiap pustakawan adalah sebagai berikut:

\section{1) Menyampaikan sikap positif}

Sikap positif merupan salah satu ketrampilan yang harus dimiliki oleh pustakawan. Untuk dapat menampilkan kesan positif pada pemustaka maka ada beberapa hal yang perlu diperhatikan oleh pustakawan, yaitu:

\section{2) Memperhatikan penampilan}

Pakaian yang dikenakan pustakawan tidak harus mahal, terkesan mencolok atau bahkan terkesan norak. Cara berpakaian yang rapi dan sopan dapat dilakukan dengan mengenakan seragam, selain itu seragam juga dapat menunjukkan kekompakan pengelola perpustakaan, tentunya dalam hal ini pakaian yang dikenakan harus dikondisikan sesuai lingkungan perpustakaan dan masyarakat yang dilayani. Penampilan tidak hanya didukung dengan pakaian yang dikenakan melainkan juga penampilan fisik seorang pustakawan itu sendiri, misalnya potongan rambut yang rapi dan pemakaian parfum yang wangi. Penampilan yang baik dan sopan sematamata ditujukan untuk memberikan kesan pertama yang positif kepada pemustaka.

3) Komunikasi yang baik

Di dalam perpustakaan sendiri komunikasi terlihat sebagai proses yang terus menerus, mempengaruhi setiap elemen dalam sebuah lembaga dan karena sifatnya yang terus menerus, maka komunikasi menjadi bersifat dinamis, bergantung pada tempat, waktu, dan kondisi di mana komunikasi itu berjalan. Peran pustakawan dalam berkomunikasi dengan pemustaka sangatlah vital.
Seorang pustakawan diharapkan dapat menguasai tehnik komunikasi yang baik, dapat menimbulkan sikap saling pengertian dan saling menguntungkan antara kedua belah pihak baik pustakawan dan pemustaka. Kunci komunikasi yang efektif adalah mencoba mengerti dan melakukan tindakan yang bisa memberikan kepuasan pemustaka. Pustakawan dituntut untuk mengetahui, kemudian mempraktekkan berbagai macam dan bentuk komunikasi supaya perpustakaan yang dikelolahnya mampu memahami kebutuhan informasi yang dibutuhkan oleh penggunanya.

4) Bahasa tubuh dan sikap yang baik

Pustakawan harus memperhatikan bahasa tubuh dan sikap yang baik dalam memberikan pelayanan kepada pemustaka. Dengan hal ini diharapkan pemustaka merasa nyaman dan tidak segan atau bahkan malu untuk bertanya kepada pustakawan ketika informasi yang dibutuhkan tidak didapatkan. Bahasa tubuh dan sikap yang baik akan menimbulkan respon yang positif dari pemustaka, dan respon positif akan mengembalikan citra baik perpustakaan dalam menyediakan sumber informasi dan peran pustakawan dalam pelayanan informasi di perpustakaan.

\section{5) Menjaga nada bicara}

Pustakawan dalam berkomunikasi harus memperhatikan etika berbicara, misalnya dengan menjaga nada bicaranya. Sebelum berkomunikasi dengan pemustaka, pustakawan juga harus memiliki pengetahuan dan pemahaman keanekaragaman budaya, pustakawan akan dapat memberikan pelayanan yang terbaik kepada pemustaka yang datang ke perpustakaan. Selain itu pustakawan juga dituntut untuk memiliki kemampuan pengelolaan diri dan emosi yang baik. 
Kemampuan mengelola emosi berarti mampu mengekspresikan dengan tepat perasaan yang sedang dialaminya. Ketepatan ekspresi perasaan berarti mampu mengungkapkan perasaan dengan benar sesuai dengan yang terjadi pada dirinya, dengan kata-kata yang tidak menimbulkan makna ganda terhadap orang yang bersangkutan pada situasi dan kondisi yang tepat (Spillane, 2006: 138139).

6) Menggunakan media komunikasi secara efektif

Pustakawan harus memiliki kemampuan dalam menggunakan media komunikasi secara efektif. Saat memberikan pelayanan kepada pemustaka menggunakan media komunikasi misalnya komputer pustakawan harus bertindak secara cepat dan tepat tanpa membuat pemustaka terlalu lama menunggu untuk mendapatkan pelayanan yang diinginkan. Dalam hal ini pustakawan dituntut untuk menguasai teknologi informasi /secara efektif.

\section{7) Menjaga energi}

Pustakawan harus tetap konsisten menjaga energinya dalam memberikan pelayanan kepada pemustaka, artinya pelayanan yang dilakukan pustakawan tidak berubah atau berkurang meskipun jadwal pelayanan padat. Hal ini dilakukan agar pemustaka tetap mendapatkan pelayanan yang maksimal. Tujuan pustakawan dalam menjaga energi adalah untuk menghindari stress dalam bekerja, karena pelayanan jasa membutuhkan keadaan fisik yang kuat. Stress dapat dikurangi dengan cara mengambil jeda selama 15 menit dengan melakukan peregangan (strech), berdansa atau mendengarkan musik (Sunarto, 2005, 6).
8) Mengenali kebutuhan pemustaka

Mengenali pelanggan berarti memahami harapan dan kebutuhan mereka, jika harapan dan kebutuhan pelanggan dipenuhi maka kepuasan pelanggan akan terjadi (Sunarto, 2005: 6). Pustakawan harus mengidentifikasi dan mengenali terlebih dahulu siapa pemustaka yang akan dilayaninya. Hal ini dilakukan agar pelayanan yang diberikan sesuai dengan kebutuhan yang diinginkan pemustaka. Adapun hal-hal yang perlu diketahui oleh pustakawan adalah sebagai berikut:
a) Siapa pemustakanya,
b) Apa yang diinginkan pemustaka,
c) Apa yang dibutuhkan pemustaka,
d) Apa yang dirasakan pemustaka,
e) Apakah pemustaka merasa puas,
f) Apakah pemustaka kembali lagi.

Seorang pustakawan harus jeli dalam melihat siapa pemustakanya dan apakah pemustaka tersebut butuh bantuan pustakawan atau tidak. Hal paling penting yang harus dilakukan pustakawan adalah mereka harus memberikan hak yang sama kepada pemustakanya. Di samping mengenali kebutuhan pelanggan atau pemustaka, pustakawan harus mengenali karakteristik pemustaka tersebut. Menurut Septiyantono dalam Priyanta (2008: 144-145) ada berbagai sifat dan karakter Pemustaka yang perlu dipahami agar pustakawan dapat menghadapinya dengan baik. Berikut ini beberapa karakter dan cara menghadapi pemustaka yang:

a) Pendiam, dapat dihadapi dengan penyambutan secara ramah untuk menarik perhatiannya.

b) Tidak sabar, dapat menawarkan kita secara maksimal dan secepat mungkin. 
c) Banyak bicara, dengan menawarkan bantuan dan mengalihkan perhatian pada hal-hal yang ditawarkan dengan penjelasannya.

d) Banyak permintaan, dengarkan dan segera penuhi permintaannya serta minta maaf dan memberi alternatif lain apabila permintaan tidak tersedia.

e) Peragu, dengan memberi kepercayaan, tenang, dan tidak memberikan banyak pilihan namun mengikuti seleranya.

f) Senang membantah harus dihadapi dengan tenang, dan jangan pernah terpancing untuk berdebat.

g) Lugu, dihadapi dengan menerima apa adanya, menanyakan keperluannya dan melayani berdasarkan permintaan.

h) Siap mental, dihadapi dengan membiarkannya memilih yang dikehendaki, tanpa banyak bertanya, memuji pemakai dan ucapkan terima kasih atas kunjungannya.

i) Yang curiga, dihadapi dengan memberikan jaminan yang baik dan jangan tunjukkan sikap seolah-olah petugas lebih unggul.

j) Yang sombong, dihadapi dengan tenang, sabar menghadapi sikapnya dan tidak terlalu serius, serta berikan kesan bahwa pengguna tersebut perlu dihormati.

\section{9) Memenuhi kebutuhan pemustaka}

Sebelum memberikan pelayanan kepada pelanggan (pemustaka), pustakawan harus mengetahui beberapa kebutuhan dasar pemustaka. Pustakawan harus mengetahui dan dapat memahami pemustaka dengan baik sebelum memberikan pelayanan, hal ini dilakukan agar pelayanan yang diberikan tidak menyimpang dari kebutuhan pemustaka. Pustakawan diharapkan cepat tanggap dalam merespon pertanyaan tentang informasi yang dibutuhkan oleh pemustaka, dapat memberikan penelusuran informasi yang dibutuhkan dengan cepat dan tepat, mampu membedakan antara hal yang penting dan tidak penting tentang informasi.

Menurut Martin (2005, 42) ada 4 kebutuhan dasar pelanggan yang harus diketahui yaitu:

a) Kebutuhan untuk dipahami,

b) Kebutuhan untuk merasa diterima,

c) Kebutuhan untuk merasa penting,

d) Kebutuhan akan kenyamanan,

Setelah mengetahui siapa pemustaka dan kebutuhan yang diinginkannya, maka tugas seorang pustakawan adalah memenuhi kebutuhan pemustaka tersebut. Adapun beberapa cara untuk memenuhi kebutuhan pemustaka adalah sebagai berikut:

a) Peka akan ketepatan waktu,

b) Berada satu langkah di depan pemustaka,

c) Tetap memperhatikan pemustaka,

d) Mengedepankan kebutuhan pemustaka,

Pustakawan tidak harus menunggu pemustaka bertanya atau meminta bantuan terlebih dahulu dalam memberikan pelayanan. Pustakawan juga diharapkan lebih sigap dalam menyelesaikan permasalahan yang dihadapi pemustaka. Pelayanan selangkah di depan ini dapat dilakukan oleh pustakawan dengan mengidentifikasi siapa pemustakanya dan apa kebutuhannya terlebih dahulu. Dalam memberikan pelayanan yang bermutu perlu kiranya pustakawan memperhatikan etika berkomunikasi yang baik, karena dengan komunikasi yang baik pemustaka akan merasa nyaman, puas dan merasa dihargai. 
10) Memastikan pemustaka kembali lagi

Kepuasan pemustaka dapat dijadikan sebagai tolak ukur bagusnya pelayanan di dalam perpustakaan. Kepuasan pemustaka terhadap pelayanan pustakawan dapat dilihat dari meningkatnya jumlah pengunjung perpustakaan dan interaksi pemustaka dengan pustakawan yang lebih aktif. Setelah pelayanan yang maksimal dilakukan maka secara tidak langsung pemustaka akan merasa puas terhadap pelayanan tersebut, mereka akan merasa nyaman dan tertarik untuk kembali lagi ke perpustakaan.

Permasalahan sumberdaya manusia di perpustakaan dapat diselesaikan oleh pihak manajemen perpustakaan. Salah satu upaya untuk meningkatkan kualitas sumber daya manusia di perpustakaan adalah dengan mengikutsertakan pegawai maupun pustakawannya dalam kegiatankegiatan pelatihan, seminar-seminar, lokakarya, workshop dan kongres atau rapat-rapat kerja di bidang kepustakawanan dengan maksud agar ilmu yang dimilikinya semakin bertambah dan dapat mengikuti perkembangan zaman dalam disiplin ilmu atau profesi yang dijalaninya. Tentu dengan semakin tinggi dan bertambahnya ilmu yang dimiliki pustakawan, maka hal ini pada akhirnya akan dapat meningkatkan kualitas pelayanan perpustakaan kepada pengguna (pemustaka). Sehingga pemustaka mendapatkan kepuasan serta memiliki minat untuk mengunjungi perpustakaan guna mendapatkan informasi yang dibutuhkan.

\section{KESIMPULAN}

Kesimpulan dari pembahasan makalah ini adalah bahwa untuk menghadapi kebutuhan pemustaka akan informasi yang semakin kompleks dan beragam, seorang pustakawan harus memiliki keterampilan sosial dalam rangka memberikan pelayanan yang bermutu kepada pemustaka. Keterampilan sosial adalah kemampuan seseorang untuk mengelola emosi yang berhubungan dengan orang lain, baik individu atau kelompok, sehingga dapat terjalin suatu interaksi sosial dan komunikasi yang baik dan efektif. Keterampilan sosial yang harus dimiliki pustakawan dalam memberikan pelayanan bermutu kepada pemustaka adalah dengan menyampaikan sifat positif, mengenali kebutuhan pemustaka dengan cara memahami karakteristik tiap-tiap pemustaka, memenuhi kebutuhan pemustaka berdasarkan analisis kebutuhan dasar pemustaka, dan memastikan pemustaka kembali lagi atau merasa puas. Selain itu pustakawan juga harus memiliki kemampuan interpersonal yang baik salah satunya ditunjukkan dengan berkomunikasi secara efektif kepada pemustaka. Komunikasi yang baik merupakan kunci utama pelayanan, untuk lebih dekat dengan pemustaka dan membuat pemustaka merasa dihargai.

\section{DAFTAR PUSTAKA}

Bawden, D., \& Blakeman, K. IT. (1990). Strategies For Information Management. London: Butterworth.

Cartledge, G. \& Milburn, J. F. (1995). Teaching social skills to children $\mathcal{E}$ youth: innofative approachef (3rd ed.). Massachussetts: Allyn and Bacon

Dewan Perwalikan Rakyat Republik Indonesia. (2007). Undang-Undang Republik Indonesia Nomor 43 Tahun 2007 Tentang Perpustakaan. http:/ / www.pu.go.id/satminkal/i tjen/

peraturan/UU_43_2007_PERPUST

AKAAN.pdf. Diakses pada 10 Oktober 2015 pukul 12.22. 
Hersen, M dan Bellack, A. S. (1977). Behavior modification: An introductory textbook, Baltimore: Williams \& Wilkins.

Kasmir. (2005). Etika costomer service. Jakarta: PT Raja Rasindo Persada.

Kotler, P. (2003). Marketing Management 11th Edition. New Jersey: Prentice Hall.Inc.

Rahayu, L., dan Anggraini Kiemas, R. (2011). Pelayanan Bahan Pustaka. Jakarta: Universitas Terbuka.

Lovelock, C. (2002). Service Marketing In Asia. Singapore: Prentice Hall Inc.

Martin, W. B. (2005). Quality Costomer Service. Jakarta: PPM.

Menteri Pendayagunaan dan Aparatur Negara. (1993). Keputusan Menteri Pendayagunaan Aparatur Negara) Nomor KEP/81/M.PAN/1993 tentang penyelenggaraan pelayanan publik. http:/ / pustaka.pu.go.id/new/kata $\log$

detail.asp?kode=BIRO\%20UMUM0 5359\&jenis=HUKUM. Diakses 10 Oktober 2015 pukul 12.20.

Merrel. (2008). Helping Students Overcome Depression and Anxiety:A Practical Guide (2nded.).New York: The Guilford Press.

Milburn, J.F., dan Cartledge, C. (1995). Teaching Social Skills to Children and Youth Inovative Approach.Third edition. Massachusetts: Allyn and Bacon.

Moenir, H. A. S. (2006). Manajemen Pelayanan Umum di Indonesia. Jakarta: PT. Bumi aksara.

Parasuraman, V. A. Z., and Berry (2002). Delivering Service Quality. New York: McMillan.

Pasolong, H. (2007). Teori Administrasi Publik, Bandung: ALFABETA.

Priyanta, I. F., dkk. (2008). Perpustakaan dan Kebangkitan Bangsa Yogyakarta: LPII.
Pusat Bahasa Departemen Pendidikan Nasional, (2008). Kamus Besar Bahasa Indonesia, Jakarta: Balaipustaka.

Rahayuningsih. (2007). Pengelolaan Perpustakaan. Jakarta: Graha Ilmu.

Ratminto dan Septi, W. A. (2005). Manajemen Pelayanan. Yogyakarta: Pustaka Pelajar.

Sampara, L. (2000). Manajemen Kualitas Pelayanan. Jakarta: STIA LAN Press.

Sinambela, L.P. (2005). Reformasi Pelayanan Publik; Teori, Kebijakan dan Implementasi, cetakan kelima. Jakarta: PT. Bumi Aksara.

Slaby, D. A., Combs, M. L. (1997). Social Skill Training with Children. New York: Plennun Press.

Spillane, J. J. (2006). Managing Quality Customer Service Pelayanan yang Berkualitas. Yogyakarta: Universitas Sanata Dharma.

Sunarto. (2005). Manajemen Sumber Daya Manusia Strategik. Yogyakarta: Penerbit Amus.

Sutarno. (2005). Tanggung Jawab Perpustakaan dalam Mengembangkan Masyarakat Informasi. Jakarta: Panta Rei.

Tjiptono, F. (2005). Pemasaran Jasa. Malang: Bayu

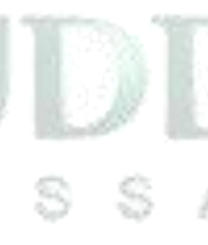

